\title{
Digital transformation of energy in the Russian Federation: project approach, realities and prospects
}

\author{
Varvara Kulkova ${ }^{1, *}$, Ekaterina Khusainova ${ }^{1}$, Nina Serkina ${ }^{1}$, Elena Dolonina ${ }^{1}$, and Zoya Shackih $^{1}$ \\ ${ }^{1}$ Kazan State Power Engineering University, Department of Economics and Organization of Production, 420066, Kazan, str. \\ Krasnoselskaya, 51, Russian Federation
}

\begin{abstract}
The digital transformation of energy infrastructure is a priority task for the development of energy in the Russian Federation, implemented in a project-based approach - in the initiation of the departmental project "Digital Energy" by the Ministry of Energy of the Russian Federation. The project can get an additional impetus for development in the current conditions of the "crisis of 2020", which are positioned as a trigger for digital transformations in the sectors of the economy. To what extent are the activities of the Digital Energy project aimed at digital transformation of the energy industry and do consumers see changes when they receive services? Should we expect an intensification of the digital transformation of the energy sector in the context of the 2020 crisis? The questions are acute and relevant, which determine the purpose of the study - to assess the digital transformation of the energy sector in the Russian Federation implemented in the project approach in the context of the "crisis of 2020", revealing the expert opinion of the stakeholders. Research methods: end-to-end analysis of project activities in a comparative assessment with foreign factography; secondary analysis of interviews with top managers of energy enterprises on the issue of digitalization and digital transformation of energy; survey of individualsconsumers of electricity $(\mathrm{N}=60)$. The conducted research provides a basis for the conclusion about the implementation of the digitalization process in the energy sector and does not allow identifying the conditions of the "crisis of 2020" as a trigger for the transition of digitalization to the digital transformation of the energy industry. Identified consumers-detractors, whose positions are working to identify "points of growth" of digital transformation of the electric power industry in the future.
\end{abstract}

\section{Introduction}

The modern digital reality, which is the result of the fourth industrial revolution of Industry 4.0, affects all sectors of the national economy, transforming industries and services on a different scale and dynamics of development, which gives rise to intersectoral and intraindustry differentiation of digital maturity, changing consumer behavior and expectations, is ultimately designed to increase customer satisfaction. In the characterization of intersectoral differentiation, it is known that a high level of digital maturity has reached the field of media and tourism, while the energy industry shows an initial level of "digital maturity" [1]. However, the emerging macro-conditions of a global nature, in particular the transition to distribution generation and renewable energy sources [2-8], the change in consumer behavior in the development of energy democracy [916], cause energy companies to adapt business processes to a digital format.

At the same time, the cross-industry and intraindustry differentiation of the digital maturity of companies is accompanied by the absence of terminological unity in the designation and semantic interpretation of the concepts and processes of digital reality, for example, such as digitalization and digital transformation.

The digital transformation of energy infrastructure is a priority for energy development in the Russian Federation. To implement the task, the Ministry of Energy of the Russian Federation uses the project approach, in particular, the departmental project "Digital Energy" was initiated [17]. The implementation of the Digital Energy project forms among consumers when receiving the services of energy companies a model of expectation behavior in the context of the "mobile mentality" due to the digital era.

The Digital Energy project may receive an additional impetus in the current conditions of the "2020 crisis," which are positioned as a trigger for digital transformation in the sectors of the national economy [18].

How much are the events of the Digital Energy project aimed at digital transformation of the energy industry and do consumers see changes in receiving services? Should we expect to intensify the digital transformation of energy in the context of the "crisis 2020"? The issues are acute and relevant, which determine the goal of the study - to evaluate the digital transformation of energy in the Russian Federation

$\overline{\text { *Corresponding author: kulkova77@mail.ru }}$ 
implemented in the project approach in the context of the "2020 crisis," revealing the expert opinion of stakeholders.

The significance of the research results lies in the scientific justification and identification of the processes of the transition of energy to digital reality in the Russian Federation, provided for in the framework of the departmental project "Digital Energy," for adequate and prompt monitoring, response in the development of corrective measures in the implementation of the project approach to digital energy transformation.

The novelty of the research results consists in revealing the realities and prospects of the digital transformation of the energy industry in the modern conditions of the "crisis 2020" based on the consolidation, on the one hand, of the obtained expert assessments of the top managers of the energy industry enterprises, who are persons, decision makers, opinion leaders and carriers of transformations in the industry, on the other hand, the identified expectations of consumers in obtaining the services of energy companies.

\section{Materials and Methods}

\subsection{Brief Literature Review}

Many researchers draw attention to the lack of a unified approach to the definition of categories and processes of digital reality [18-22]. So, a number of researchers emphasizing the infidelity of understanding digitalization at the same time do not distinguish between digitalization and digital transformation, identifying these concepts [1]. In practice, companies (Siemens, Elma 365, ets) broadcast the distinction between digitalization as a process of using digital technologies in activities and digital transformation as changes in the business model of the company by improving organizational activities supported by modern digital technologies [23, 24]. The presented study develops the last approach, in other words, digital transformation is considered as a deeper process (regarding digitalization), changing the mentality, concept of doing business and business activities affecting changes: supply (offering value), operational model (key partners, activities, resources), financial model (cost structure and income flows), clients (channels of interaction and relationships).

Researchers demonstrate unity in the position of highlighting the key value of digital transformation of companies, which is not only resource savings, but also the focus on increasing customer satisfaction [1].

A model for describing the digital transformation of energy companies is known, based on the allocation of processes by target groups and cost creation stages, in particular: customer interaction processes/cost creation stages transportation and distribution, sales and service, corporate center; Supplier Relationship Processes/Manufacturing, Transportation and Distribution Maintenance/Manufacturing, Transportation and Distribution Processes Internal processes/manufacturing, transportation and distribution, sales and maintenance [1].

Promising areas of energy digitalization are disclosed by Bloomberg in the forecast developments of the size of the digital technologies market in the energy sector, illustrating both the species structure and industry directions of digital technologies, namely: operation of thermal power plants, smart meters, automation of distribution systems, home power consumption management systems, ensuring the stability of power systems with unstable generation sources, operation and maintenance of VES, operation and maintenance of SES [25].

The prospects for the development of digital energy of the Russian Federation are set until 2024 in the departmental project of the Ministry of Energy of the Russian Federation "Digital Energy." The prerequisites for developing a departmental project are laid down in Decree of the President of the Russian Federation dated 07.05.2018 No. 204 "On National Goals and Strategic Objectives for the Development of the Russian Federation for the Period until 2024," the Program "Digital Economy of the Russian Federation," the Strategy for Scientific and Technological Development of the Russian Federation. The goal of the Digital Energy project is to "create conditions for the digital transformation of the fuel and energy complex of Russia, the introduction of digital technologies and platform solutions" [17]. Project directions: creating conditions for the development and development of digital services and solutions in the fuel and energy sectors; digital electric power industry; digitalization of the oil and gas complex; digitalization of the coal industry.

In 2020, on the basis of the Department of Economics and Production Organization of Kazan State Energy University, the first author conducted an initiative study "State of the Energy Sector in the Context of the" Crisis 2020 ": challenges, anti-crisis events, "growth points" through the eyes of experts "showed that" Digitalization of energy as a "growth point" in the "crisis 2020," "Assessment of the current level of development of digitalization of energy" are the statements that appear in interviews most often, and about which there were most divergent views [26].

Based on the above-described problems and a review of the literature, the following are highlighted as areas of digital transformation of the energy sector in the context of the "crisis 2020" to be studied: the realities of the introduction of digital technologies by fuel and energy companies in the Russian Federation; prospects for digital transformation of the industry set in the context of the Digital Energy project; expert assessments of industry leaders and consumers of digital transformation services.

\subsection{Methods}

The goal of the study and the areas of digital transformation of energy allocated for the study determined the choice of the following research methods. 
First. Description method: in the cases of fuel and energy companies of the Russian Federation names of introduced digital technologies (at least 10 enterprises) with a subsequent comparative assessment with foreign factography, in particular, the areas of development of the digital technology market in the energy sector, allocated by Bloomberg New Energy; prospects for the digital transformation of energy in comparison of directions and targets of the project to identify the nature of digital energy laid down in the departmental project.

Second. To identify the expert opinion of stakeholders, the following were conducted: a secondary analysis of interviews of top managers of energy enterprises on the problem of digitalization and digital transformation of energy, obtained as part of an earlier study "State of the energy industry in the context of the" crisis 2020 "[26]; survey of individuals-consumers of electricity $(\mathrm{N}=60)$. The sample included residents of one sleeping district of the capital of the Republic of Tatarstan, which is due to the availability of the expert base of the study. The survey was organized in the village of individual housing construction (IHC) and a residential apartment building. A questionnaire on satisfaction with the services of the electric power industry (electricity supply) in digital reality was developed. The questionnaire was distributed in groups created by residents in the social network "WhatsApp," completed questionnaires were sent to a specially created group for questionnaire. The results of the questionnaire survey were processed in the SPSS software product.

\section{Results and Discussion}

The realities of the introduction of digital technologies in the companies of the fuel and energy complex of the Russian Federation for 2020 are given in Table 1.
Table 1. Introduction of digital technologies by Russian fuel and energy companies [17].

\begin{tabular}{|c|c|}
\hline Company & Digital technology \\
\hline \multirow{3}{*}{ Rosneft } & Cloud computing model \\
\hline & Intelligent field \\
\hline & Smart well \\
\hline \multirow{4}{*}{ Lukoil } & Center for spatial visualization \\
\hline & Big data modeling \\
\hline & Intelligent field \\
\hline & Smart well \\
\hline \multirow{2}{*}{ Tatneft } & Engineering Center \\
\hline & Smart well \\
\hline \multirow{2}{*}{ Gazprom } & Engineering centers \\
\hline & Intelligent field \\
\hline \multirow{5}{*}{ Gazprom Neft } & $\begin{array}{l}\text { Geological Information Analysis } \\
\text { Geomat }\end{array}$ \\
\hline & Refinery digital twin \\
\hline & Smart well \\
\hline & Automated control center \\
\hline & Industrial Internet Implementation \\
\hline \multirow[b]{2}{*}{ SUEK } & Intelligent career \\
\hline & $\begin{array}{l}\text { Complex of intelligent systems to } \\
\text { ensure work safety }\end{array}$ \\
\hline \multirow{3}{*}{ Rosseti } & Smart metering devices \\
\hline & Smart grids \\
\hline & Digital substations \\
\hline $\begin{array}{c}\text { Federal Grid } \\
\text { Company UES }\end{array}$ & Substation equipment telecontrol \\
\hline Tt group & $\begin{array}{l}\text { A software package for building } \\
\text { energy modes }\end{array}$ \\
\hline Rotek & $\begin{array}{l}\text { Digital system for predicting the state } \\
\text { of equipment of gas power plants }\end{array}$ \\
\hline
\end{tabular}

A comparative analysis of digital technologies of the fuel and energy complex of the Russian Federation with the global factography of the development directions of the digital technology market in the energy sector indicates that not all of the potentially promising technologies are involved in energy companies of the Russian Federation.

Prospects for the digital transformation of energy in the Russian Federation in the project approach are outlined in Table 2. 
Table 2. Description of directions and targets of the Digital Energy Project of the Russian Federation [17].

\begin{tabular}{|c|c|}
\hline Direction & $\begin{array}{c}\text { Target indicator } \\
\end{array}$ \\
\hline \multirow{5}{*}{$\begin{array}{l}\text { Creation of } \\
\text { conditions for the } \\
\text { development and } \\
\text { development of } \\
\text { digital services and } \\
\text { solutions in the fuel } \\
\text { and energy sector }\end{array}$} & $\begin{array}{l}40 \% \text { share of key organizations } \\
\text { in the fuel and energy complex } \\
\text { using digital technologies and } \\
\text { platform solutions operating } \\
\text { within the unified information } \\
\text { environment of the fuel and } \\
\text { energy complex of Russia }\end{array}$ \\
\hline & $\begin{array}{l}\text { The share of Russian fuel and } \\
\text { energy companies using } \\
\text { advanced production } \\
\text { technologies will grow to } 14 \%\end{array}$ \\
\hline & $\begin{array}{c}100 \% \text { share of organizations in } \\
\text { the Russian fuel and energy } \\
\text { complex using security tools for } \\
\text { information transmitted over } \\
\text { global networks in the total } \\
\text { number of surveyed } \\
\text { organizations }\end{array}$ \\
\hline & $\begin{array}{l}11 \% \text { share of specialists in } \\
\text { information and communication } \\
\text { technologies in organizations of } \\
\text { the fuel and energy complex of } \\
\text { the Russian Federation }\end{array}$ \\
\hline & $\begin{array}{l}\text { The costs of training employees } \\
\text { by organizations of the Russian } \\
\text { fuel and energy complex } \\
\text { associated with the development } \\
\text { and use of information and } \\
\text { communication technologies will } \\
\text { increase by } 7 \%\end{array}$ \\
\hline \multirow{3}{*}{ Digital energy } & $\begin{array}{c}\text { Reduce power outages and } \\
\text { average technology disturbance } \\
\text { rates (SAIDI / SAIFI) by } 5 \% \text { by } \\
2024\end{array}$ \\
\hline & $\begin{array}{l}\text { Increasing the level of technical } \\
\text { condition of production assets of } \\
\text { the electric power industry for } \\
\text { facilities by } 5 \% \text { by } 2024 \text { without } \\
\text { increasing the cost of } \\
\text { maintaining the technical } \\
\text { condition }\end{array}$ \\
\hline & $\begin{array}{l}\text { Reduction by } 20 \% \text { of accidents } \\
\text { at electric power facilities related } \\
\text { to the technical condition of } \\
\text { production assets by } 2024\end{array}$ \\
\hline \multirow{3}{*}{$\begin{array}{l}\text { Digitalization of } \\
\text { the oil and gas } \\
\text { complex }\end{array}$} & $\begin{array}{l}\text { Increasing the oil recovery factor } \\
\text { by } 5-10 \% \text { at "digital fields" }\end{array}$ \\
\hline & $\begin{array}{l}\text { Decrease in operating costs in } \\
\text { "digital fields" by } 10 \%\end{array}$ \\
\hline & $\begin{array}{c}\text { Reduction of capital } \\
\text { expenditures on "digital fields" } \\
\text { up to } 15 \% \\
\end{array}$ \\
\hline \multirow{2}{*}{$\begin{array}{l}\text { Digitization of the } \\
\text { coal industry }\end{array}$} & $\begin{array}{l}\text { Increase in underground and } \\
\text { open pit mining by } 5-7 \% \text { by } \\
2024\end{array}$ \\
\hline & $\begin{array}{l}\text { Improving the safety level of } \\
\text { mining operations }\end{array}$ \\
\hline
\end{tabular}

An assessment of the targets of the Digital Energy project with a digital transformation model shows that the project's events are aimed at digitalizing the industry and do not implement digital transformation, which is traced to the designation of project directions. The identified discrepancy in the tasks and characteristics of the result according to the project directions works on verification of the output. Thus, as part of the direction of digitalization of the oil and gas complex, the task was set "to create a system for coordinating the digital transformation of the oil and gas complex of Russia," and as a result, the concept of digitalization of the oil and gas complex should be developed. The situation is similar for the digitalization of the coal industry. A meaningful analysis of the tasks and characteristics of the result according to the project directions gives reason to conclude that the processes of interaction with customers are not stated in the Digital Energy project either in the production sector, or at the level of transportation and distribution, service. In fairness, the project in the direction of digitalization of the electric power industry set the task of "Improving the level of reliability of energy supply to consumers," but the result is formed in the production sector, does not affect transportation and distribution processes (for example, the development of systems for notifying customers about power outages and other problems), sales and service (an application that allows customers to quickly access basic data). Recent circumstances do not work to increase public satisfaction with the services of energy companies as the main target orientation of digital transformation, which once again confirms the conclusion made by us that the departmental project "Digital Energy" in the Russian Federation does not implement digital transformation, but is focused on the introduction of digital technologies, that is, digitalization. At the same time, the initiation of the Digital Energy Project creates expectations among consumers for convenient user services (applications) adapted to modern information technologies, the shortage of which exists despite the digital reality.

The identified expert assessments of industry leaders confirm the orientation of the industry towards the process of digitalization, and not digital transformation of energy. So, experts broadcast that digital technologies are used in organizing remote work of employees, electronic forms of document management, and strengthening digital control. The processes of digital transformation of production activities, maintenance, interactions with customers, partners on a single platform are postponed "until the best times" due to the "crisis 2020."

Industry leaders rate the level of digital maturity of energy from the "initial" to the "good average" in different ways. It is thought that the variation of expert assessments, on the one hand, is a consequence of the divergence of the terminological apparatus, on the other hand, this is a problem not only of a scientific nature the certainty of the categorical and conceptual apparatus, but also the guidelines for the strategic development of the company in digital reality, the development of which requires an adequate assessment of the level of digital maturity of companies, which will allow developing a strategy for the development of digital transformation.

At the same time, industry leaders show solidarity in the position that "the 2020 crisis in the energy sector does not contribute to digital transformation." While at 
the federal level, the installation is broadcast that "digitalization will receive an additional impetus for development in crisis conditions" [26]. The discrepancy in the installation of federal authorities and top managers of energy companies in the region is a reflection of the dissonance between the ratio of desired results formed by the federal authorities and the real conditions in which energy companies operate. The pessimism of the position on the impact of the crisis on the intensification of the digital transformation of energy industry companies is explained by the comments of experts on the reduction in financing of digitalization programs caused by the conditions of the crisis.

A study of the satisfaction of consumers - persons in the energy industry shows that electricity services were rated as high-quality or rather high-quality by $65.3 \%$ of respondents, and $26 \%$ consider electric energy services to be low-quality or rather low-quality. The rest of the respondents found it difficult to answer. The uneven distribution of satisfaction among groups of respondents draws attention to: $80.1 \%$ of residents of a residential apartment building (ZHMD), rated electricity services as high-quality and rather high-quality. Assessing the services of the electric power industry as substandard is slightly more among the residents of the village of individual housing buildings - $60.1 \%$ compared to 10.4 in the group of residents of the housing and communal services. Respondents identify among the factors that increase satisfaction with electricity services the following: receiving an electricity bill by e-mail (60\%), using a personal account on the company's website $(40 \%)$, the opportunity to receive advice from a call center (40\%).

Among the reasons for dissatisfaction with electricity services, there is a lack of timely notification of power outages due to repair work $(90 \%)$, the Network Company OJSC website is provided but not available (not downloadable) up-to-date information on upcoming scheduled repairs $(70 \%)$, OJSC "Grid Company" and JSC "Tatenergosbyt" transfer responsibility to each other for informing on power outages in connection with scheduled repairs $(95 \%)$, the inability of JSC Tatenergosbyt to inform about power outages using digital technologies (95\%).

The obtained results empirically prove the impact of digital technologies used by energy companies in interactions with consumers on increasing the satisfaction of the latter, which is consistent with the position of a number of researchers [1]. At the same time, the response of respondents to the attractiveness of the call center consultations shows that it is relevant for consumers to maintain the quality of communication with energy companies through all channels, including the digital channel. This conclusion is reached by the researchers [1] emphasizing the preference of consumers in the variation of communication channels while maintaining the quality of service on each of them.

Residents of the village of IHC, demonstrating low satisfaction with electricity services, act as detractor consumers, whose position works to identify "growth points" of the digital transformation of the electric power industry in the future. As a well-known digital transformation provides for the integration of consumers - customers, suppliers on a single platform of the company [1], the introduction of this digitalization component in the business model of energy companies will help to offset the identified factors that limit consumer satisfaction with electricity services.

\section{Conclusions}

The results of the study provide reliable and empirical answers to the questions posed at the beginning of the article. The departmental project "Digital Energy" includes events aimed at digitalization, and not at the digital transformation of the energy industry. Industry leaders do not share the federal position that the "2020 crisis" works to intensify the digital transformation of energy. According to the results of the survey, the impact of digital technologies used by energy companies in interactions with consumers on increasing the satisfaction of the latter is proved. At the same time, for interactions with energy companies, consumers show a preference for high-quality service through all channels. Consumers-detractors have been identified, whose position works to identify "growth points" of the digital transformation of the electric power industry in the future: the integration of consumers into platform solutions of energy companies.

\section{References}

1. A. Swaminathan, J. Mefferd, Digital @ Scale: The Playbook You Need to Transform Your Company (Wiley, New Jersey, 2017)

2. E. Choi, A. Heshmati, An Empirical Studyof the Relations hipsbetween CO2 Emissions, Economic Growth and Openness (Institute of Labor Economics (IZA), Bonn, 2010)

3. A.K. Jorgenson, B. Clark, Am. J. Sociol., 118, 144 (2012) DOI: 10.1086/665990

4. J.I. Mikayilov, F.J. Hasanov, M. Galeotti, Ecol. Indic., 95, 615-628 (2018) DOI: 10.1016/j.ecolind.2018.07.051

5. M. Piłatowska, A. Włodarczyk, Montenegrin J. Econ., 14, 7-26 (2018) DOI: 10.14254/18005845/2018.14-1.1

6. A.K. Richmond, R.K. Kaufmann, Ecol. Econ., 56, 176-189 (2006) DOI: 10.1016/j.ecolecon.2005.01.011

7. P. Tapio, Transp. Policy, 12, 137-151 (2005) DOI: $10.1016 /$ j.tranpol.2005.01.001

8. R. Vavrek, J. Chovancova, Procedia Econ. Financ., 39, 526-533 (2016) DOI: 10.1016/S2212-5671(16)30295-7

9. K. Szulecki, Environmental Politics, 27:1, 21-41 (2018) DOI: 10.1080/09644016.2017.1387294

10. A. Antal, On-Line Journal Modelling the New Europe, 17, 13-27 (2015) 
11. C. Kunze, D. Becker, Energy democracy in Europe. A survey and outlook (Rosa-LuxemburgStiftung, Brussels, 2014)

12. C.A. Miller, J.Richter, J. O’Leary, Energy Research \& Social Science, 6, 29-40 (2015) DOI: 10.1016/j.erss.2014.11.004

13. C. Morris, A. Jungjohann, Energy democracy. Germanys energiewende to renewables ( Palgrave Macmillan, Basingstoke, 2016)

14. B.K. Sovacool, P.L. Blyth, Environmental Science \& Policy, 54, 304-315 (2015) DOI: 10.1016/j.envsci.2015.07.011

15. S.Sweeney, K.Benton-Connell, L. Skinner, Power to the people. Toward democratic control of electricity generation ( The Worker Institute, Cornell University and Rosa Luxemburg Foundation, Ithaca, 2015)

16. D. Szwed, B. Maciejewska, Demokracja energetyczna (Green Institute, Warsaw, 2014)

17. Departmental project «Digital Energy» of the Ministry of Energy of the Russian [Electronic resource] Available at: https://minenergo.gov.ru/node/14559 (accessed: 20.01.2021)

18. A. Auzan, The economy during and after the pandemic: lecture [Electronic resource] Available at:

https://www.econ.msu.ru/COVID19/Auzan/ (accessed: 09.01.2021)

19. V.Yu. Kulkova, Managing Sustainable Development, 5 (24), 30-34 (2019)

20. A.V. Glotko, A.G. Polyakova, M.Y. Kuznetsova, K.E. Kovalenko, R.A. Shichiyakh, M.V. Melnik, Entrepreneurship and Sustainability, 7 (3), 21812195 (2020) DOI: 10.9770/jesi.2020.7.3(48)

21. A.G. Polyakova, M.P. Loginov, E.V. Strelnikov, N.V. Usova, International Journal of Civil Engineering and Technology, 10 (2), 291-300 (2019).

22. V. Kolmakov, Journal of Critical Reviews, 7 (5), 514-518 (2020) DOI: 10.31838/jcr.07.05.109

23. V.V. Kolmakov, L.N. Rudneva, Y.E. Thalassinos, International Journal of Economics and Business Administration, 8 (2), $\quad 3-18 \quad$ (2020) DOI: 10.35808/ijeba/440

24. PWC \& SIEMENS PLM Software Alliance: A comprehensive approach to digital transformation manufacturing enterprises: Available online: https://www.pwc.ru/ru/publications/iot/transformbrochure-rus.pdf (accessed on 23.01.2021)

25. Digital transformation with ELMA [Electronic resource] Available at: https:/www.elmabpm.ru/product/bpm/digital transformation.html (accessed: 23.01.2021)
26. Bloomberg New Energy Finance [Electronic resource] Available at: http://renewnews.ru/bnef/ (accessed: 23.01.2021)

27. A. Kulachinskaya, I.G. Akhmetova, V.Yu. Kulkova, S.B. Ilyashenko, J. Open Innov. Technol. Mark. Complex., 6 (3), 60 (2020) DOI: 10.3390/joitmc6030060 